\title{
Rancang Bangun Robot Cerdas Pemadam Api Beroda dengan Pemantauan Berbasis Wifi
}

\author{
Annisa Humaira ${ }^{*}$, Rahmat Rasyid \\ Laboratorium Elektronika dan Instrumentasi, Jurusan Fisika \\ Fakultas Matematika dan Ilmu Pengetahuan Alam, Universitas Andalas \\ Kampus Limau Manis, Padang, 25163, Indonesia \\ *annisahumaira21@gmail.com
}

\begin{abstract}
ABSTRAK
Robot cerdas pemadam api beroda yang berguna untuk menemukan dan memadamkan api serta dapat bergerak secara otomatis dengan pemantauan berbasis wifi telah dirancang bangun. Robot terdiri dari sensor api KY-026 dan sensor ultrasonik HC-SR04 dilengkapi dengan kamera wifi dan pompa air yang diprogram dalam mikrokontroler Arduino UNO R3. Dari hasil pengujian didapatkan robot dapat menelusuri sirkuit, memantau keadaan sekitar, mendeteksi api dan memadamkannya dengan baik. Robot berhasil mendeteksi api dan memadamkannya berdasarkan tegangan keluaran dari sensor api KY-026. Jika tegangan sensor api berada di bawah 4,1 V maka robot akan berhenti dan mengaktifkan pompa air yang dilengkapi dengan motor servo untuk memadamkan api lilin. Namun s[ensor ultrasonik tidak bisa mengukur jarak jika posisi sensor ultrasonik terhadap dinding/objek dalam kondisi serong. Hal ini terjadi karena sudut pantul gelombang ultrasonik lebih besar dari $15^{\circ}$ sehingga receiver sensor tidak dapat menangkap gelombang yang dipantulkan objek dengan baik. Kondisi ini mengakibatkan pengukuran jarak menjadi error dan berpengaruh pada gerak robot.
\end{abstract}

Kata Kunci : Robot pemadam api, sensor api, sensor ultrasonik, Arduino UNO R3

\section{ABSTRACT}

Smart fire fighting robotic vehicle that used to find and extinguish fire and also can move automatically with monitoring based on wifi has been designed. The robot consists of a flame sensor KY-026, ultrasonic sensor HC-SR04, wifi camera and water pump which is programmed in Arduino UNO R3. Results show that the robot can trace the circuit, monitor the surrounding circumstances, detect fire and extinguish it well. The robot successfully detects the fire and extinguish it based on the output voltage of the flame sensor KY-026. If the fire sensor voltage less than $4.1 \mathrm{~V}$ then the robot will stop and activate the water pump equipped with servo motor to extinguish candle light. However, ultrasonic sensors can not measure the distance if the position of the ultrasonic sensor against the wall / object in oblique condition. This happens because the ultrasonic wave reflection angle is greater than $15^{\circ}$ so the receiver sensor can not capture the reflected waves of the object well. This condition resulted in the measurement of distance being an error and effect on robot motion.

Keywords: Fire fighting robot, flame sensor, ultrasonic sensor, Arduino UNO R3

\section{PENDAHULUAN}

Kebakaran sering terjadi akibat beberapa masalah seperti konsleting listrik, kelalaian manusia dan sebagainya. Adapun lembaga yang berwenang untuk menanggulangi kebakaran yang terjadi adalah institusi pemadam kebakaran. Namun untuk memadamkan api sampai ke bagian dalam bangunan beresiko tinggi bagi petugas pemadam. Resiko tersebut antara lain jatuh dari ketinggian, ledakan, kondisi bangunan yang terbakar, dan benda tajam. Dengan berbagai bahaya tersebut maka salah satu alternatif untuk menguranginya adalah menggunakan robot pemadam api.

Suryatini dkk. (2013) telah membuat robot cerdas pemadam api menggunakan ping ultrasonic range finder UV-TRON flame detector berbasis mikrokontroler Atmega 128. Robot ini juga dilengkapi dengan sensor garis dan kipas angin untuk pemadaman api. Namun, untuk pengaktifan pemadam api berdasarkan pendeteksian garis putih yang berada di dekat api, bukan berdasarkan keluaran sensor api itu sendiri.

Alfith (2015) telah membuat perancangan robot cerdas pemadam api dengan sensor thermal array TPA81 berbasis mikrokontroler Arduino Mega 2560. Robot ini dilengkapi dengan sensor PING untuk navigasi robot dan pemadaman api menggunakan kipas angin. Namun, penggunaan kipas angin kurang efektif karena dapat memperbesar api. 
Jupii dan Toar (2008) telah membuat robot cerdas berkaki pemadam api. Robot ini dilengkapi sensor api UVTRON, sensor jarak, sensor garis untuk pendeteksian garis putih di sekitar api dan pemadaman api menggunakan air. Namun, robot berkaki ini memiliki beberapa kekurangan yaitu pergerakan yang relatif lambat dikarenakan dibutuhkannya waktu untuk pengaturan koordinasi antar kaki robot. Selain itu pembuatan robot berkakilebih rumit.

Berdasarkan permasalahan dari penelitian sebelumnya maka pada penelitian ini dikembangkan robot cerdas pemadam menggunakan roda dengan pemantauan berbasis wifi. Robot pemadam api berodalebih banyak digunakan karena lebih mudah didesain, dibuatdan diprogram untuk bergerak pada permukaan yang datar dan tidak terlalu kasar (Lubis, 2010). Robot yang dirancang bisa mendeteksi api lilin berdasarkan tegangan keluaran dari sensor api. Pemadaman dilakukan dengan semprotan air dengan sudut pergerakan selang pompa yang diatur menggunakan motor servo agar jangkauan penyemprotan air lebih luas. Penelitian ini bertujuan untuk merancang robot pemadam api yang dapat bergerak secara otomatis untuk memadamkan api berdasarkan tegangan keluaran dari sensor api dan dapat memantau keadaan disekitar robot dengan wifi action camera.

\section{METODE}

\subsection{Perancangan Diagram Blok Sistem}

\subsubsection{Perancangan Diagram Blok Sistem Gerak Robot}

Prinsip kerja gerak robot ini diawali dengan pengukuran jarak halangan terhadap robot oleh sensor ultrasonik HC-SR04. Pengukuran jarak halangan terhadap robot dilakukan pada bagian serong kiri, serong kanan dan depan robot yang dibantu dengan motor servo 1 untuk pengaturan sudut pengukurannya. Robot akan membandingkan jarak yang terukur di masingmasing sisi untuk memutuskan ke arah mana bergerak. Robot akan bergerak maju sampai jarak robot dengan halangan $20 \mathrm{~cm}$. Jika terdeteksi adanya halangan maka robot akan mundur dan berhenti kemudian mengukur jarak kiri dan jarak kanan. Jika jarak kiri lebih besar dari jarak kanan maka robot akan berbelok ke kiri kemudian maju. Jika jarak kanan lebih besar dari jarak kiri maka robot akan belok kanan kemudian maju. Untuk diagram blok sistem gerak robot dapat dilihat pada Gambar 1.

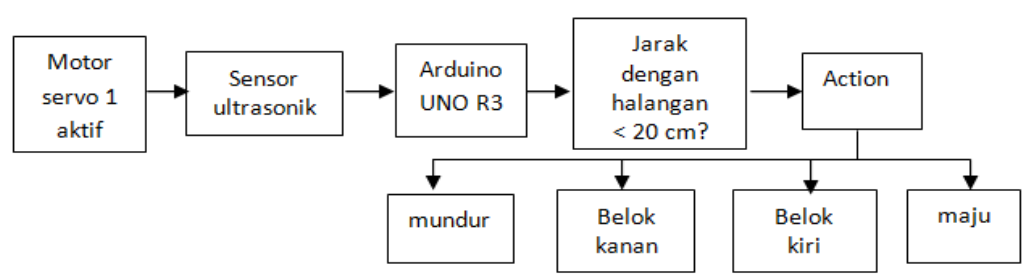

Gambar 1 Diagram blok sistem gerak robot

\subsubsection{Perancangan Diagram Blok Sistem Pemadaman Api}

Prinsip kerja pemadaman api pada robot yaitu robot akan bergerak sendiri mendeteksi halangan, pada saat itu sensor api juga sudah aktif. Jika pada saat robot bergerak robot menemukan api, dan tegangan keluaran yang terdeteksi oleh sensor api di bawah 4,1 V maka robot akan berhenti. Setelah itu relay otomatis aktif untuk menghidupkan pompa air, motor servo 2 aktif untuk memutar selang air ke kiri dan ke kanan sebesar $60^{\circ}$. Untuk diagram blok sistem gerak robot dapat dilihat pada Gambar 2.

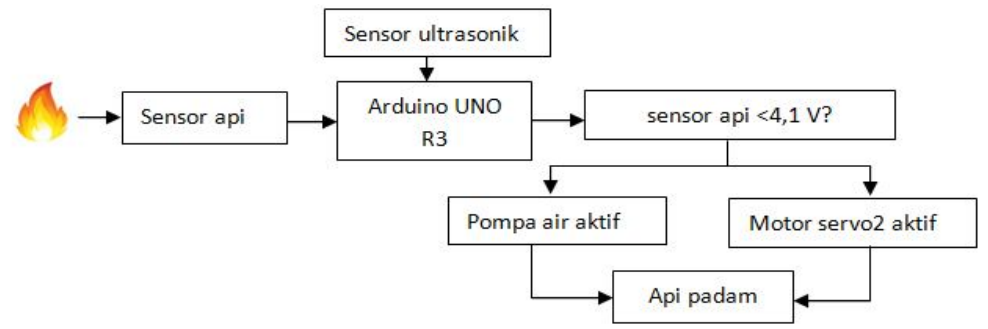

Gambar 2 Diagram blok sistem pemadaman api 


\subsection{Perancangan Bentuk Fisik Alat}

Dimensi robot berukuran $30 \mathrm{~cm}$ x $20 \mathrm{~cm}$ x $20 \mathrm{~cm}$ dan memiliki 2 buah roda kemudi dan 2 buah roda caster. Chassis robot terbuat dari 2 buah akrilik yang dihubungkan dengan baut. Chassis pertama di letakkan dibagian bawah sebagai tempat perakitan dinamo dengan roda, Arduino UNO R3, modul L298N dan relay. Sensor ultrasonik HC-SR04 dan motor servo 1 dipasang di bagian depan robot. Chassis kedua diletakkan di bagian atasnya yang digunakan sebagai tempat meletakkan bak air, pompa air, baterai, motor servo 2, selang air dan kamera. Adapun rancangan bentuk fisik alat dapat dilihat pada Gambar 3.

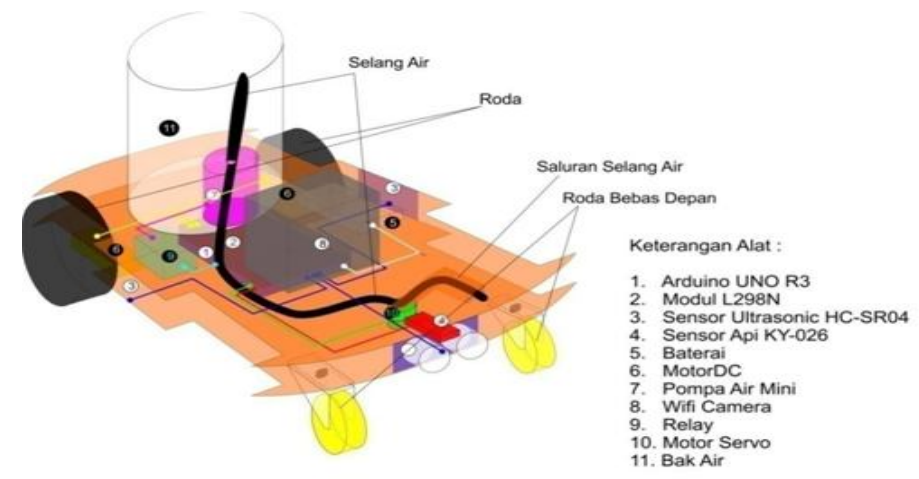

Gambar 3 Perancangan bentuk fisik alat

\subsection{Perancangan Diagram Alir}

Robot di program pada Arduino UNO R3 dengan menggunakan program Arduino IDE. Diagram alir menjelaskan bagaimana cara pemrograman robot dari awal bergerak, mencari api dan memadamkannya. Gambar 4 memperlihatkan proses perancangan logika setiap gerakan robot. Arduino UNO R3 akan membaca masukan dari sensor ultrasonik dan sensor api. Hasil pembacaan dari sensor ultrasonik dilakukan dalam 3 arah yaitu arah depan, serong kiri dan serong kanan. Setiap pergerakan robot ditentukan oleh jarak yang terukur oleh sensor pada 3 kondisi yang berbeda tersebut. Sedangkan untuk pembacaan sensor api hanya arah depan saja. Pemadam api akan aktif jika tegangan keluaran sensor api kecil dari 4,1 V.

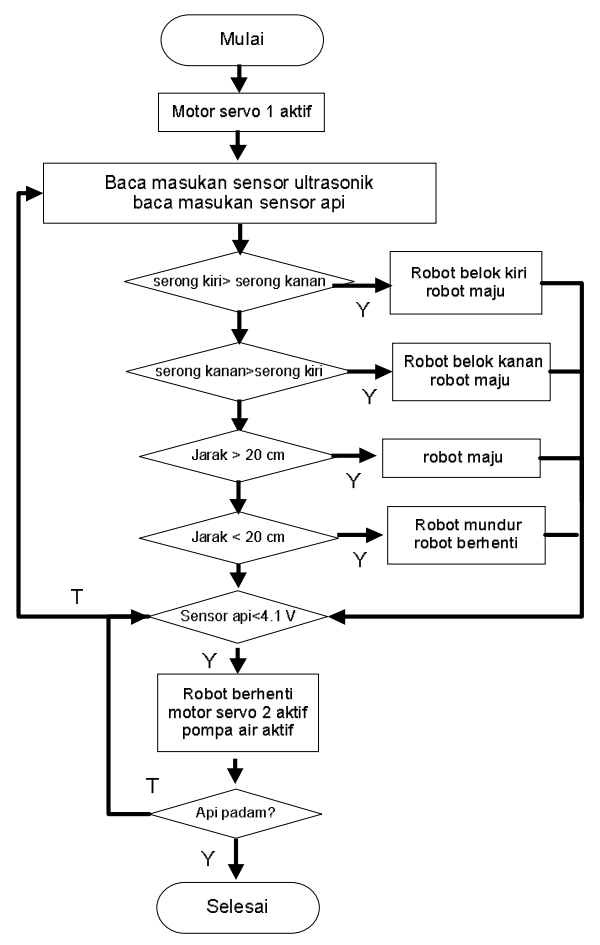

Gambar 4 Diagram alir sistem 


\subsection{Pengujian Kemampuan Alat}

Untuk pengujian kemampuan robot dilakukan di sebuah sirkuit yang terdiri dari 1 ruangan dan 1 lorong. Pada ruang tersebut akan diletakkan api lilin. Pengujian dibuat seperti ini untuk melihat kemampuan robot dalam menemukan api dan memadamkannya. Perancangan sirkuit untuk robot dapat dilihat pada Gambar 5. Ruangan berukuran $70 \mathrm{~cm}$ x $51 \mathrm{~cm}$ yang digunakan dalam Kontes Robot Pemadam Api Indonesia (KRPAI) (Ristekdikti, 2017). Untuk ukuran lorong, penelitian ini mengambil setengah dari panjang denah lapangan KRPAI dan untuk lebar lorong tetap sama dengan denah lapangan KRPAI tersebut yaitu berukuran $120 \mathrm{~cm}$ x $46 \mathrm{~cm}$. Robot mulai bergerak dari ujung lorong yang ditandai huruf $\mathrm{H}$.

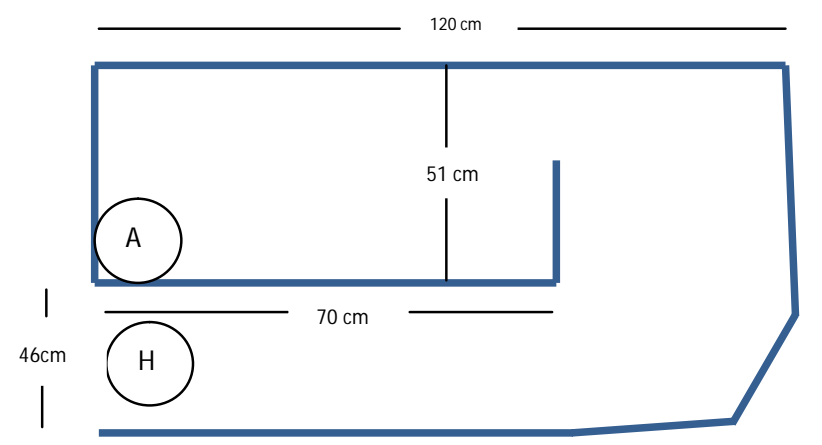

Gambar 5 Sirkuit untuk pengambilan data robot

\section{HASIL DAN DISKUSI}

Rancangan robot cerdas pemadam api beroda dengan pemantauan berbasis wifi telah dilakukan secara bertahap yang disertai dengan pengujian atau karakterisasi. Pengujian dan karakterisasi bertujuan untuk mengetahui apakah sistem yang dirancang berfungsi dengan baik atau tidak dengan analisa untuk tiap hasilnya. Gambar 6 menunjukkan rangkaian keseluruhan alat yang dirancang.

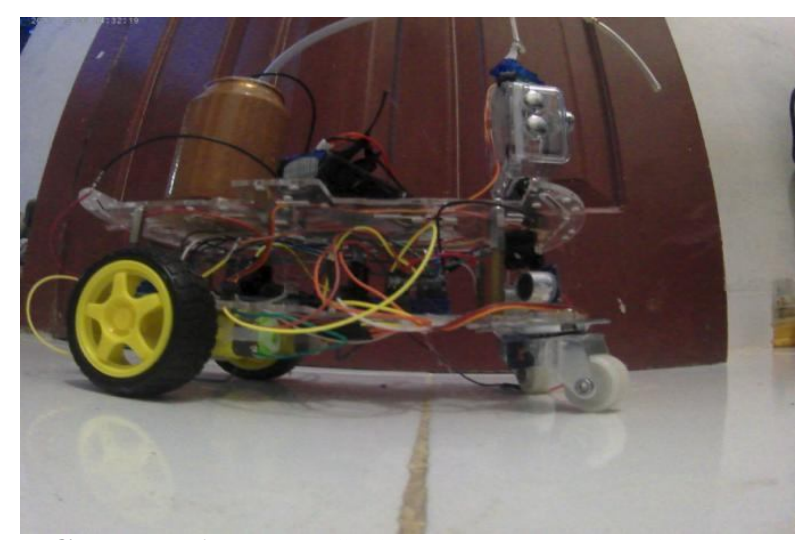

Gambar 6 Bentuk fisik robot secara keseluruhan

\subsection{Hasil Karakterisasi Sensor HC-SR04}

Proses pengambilan data karakterisasi sensor ultrasonik HC-SR04 dilakukan dengan cara membandingkan jarak yang terukur oleh sensor terhadap jarak sebenarnya.Karakterisasi dilakukan pada 1 buah sensor ultrasonik untuk pemantul padat. Halangan yang digunakan pada karakterisasi ini berupa kotak dari kardus. 


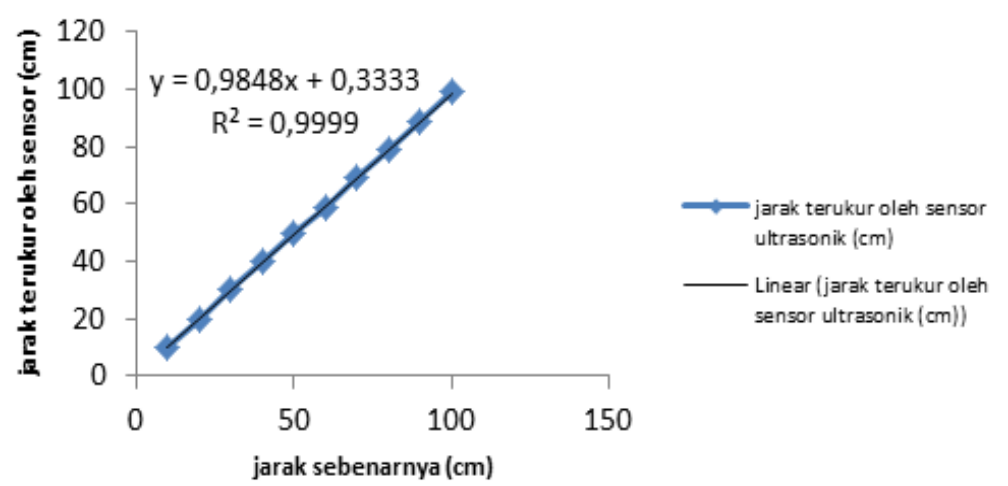

Gambar 7 Grafik jarak yang diukur sensor terhadap jarak sebenarnya

Gambar 7 memperlihatkan hubungan antara jarak yang diukur oleh sensor ultrasonik HC-SR04 dengan jarak yang sebenarnya. Fungsi transfer yang diperoleh dari data pengukuran adalah $y=$ $0,984 x+0,333$ dengan koefisien determinasi $R^{2}=0,999$. Pengukuran dilakukan mulai dari jarak $10 \mathrm{~cm}$ sampai $100 \mathrm{~cm}$ dengan variasi jarak setiap $10 \mathrm{~cm}$. Error yang didapatkan sangat kecil yaitu $0,65 \%$ yang menunjukkan bahwa sensor ultrasonik dapat bekerja dengan baik.

\subsection{Hasil Karakterisasi Sensor Api KY-026}

Karakterisasi sensor api KY-026 dilakukan dengan membandingkan tegangan yang terukur oleh sensor dengan jarak yang sebenarnya. Pengukuran dimulai dari jarak $10 \mathrm{~cm}$ sampai $100 \mathrm{~cm}$. Pada jarak 10-50 cm terjadi peningkatan tegangan yang terukur oleh sensor dari 0,03$0,14 \mathrm{~V}$. Pada pengukuran $55 \mathrm{~cm}-100 \mathrm{~cm}$ tegangan yang terukur oleh sensor hanya memiliki peningkatan sebesar 0,01 dan juga ada tegangan konstan.

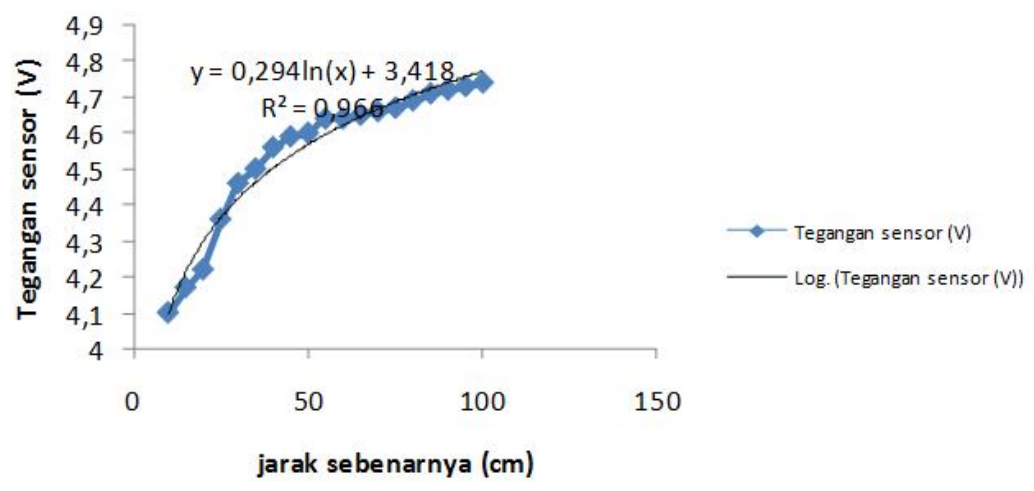

Gambar 8 Grafik tegangan keluaran sensor terhadap jarak sebenarnya

Gambar 8 memperlihatkan bahwa fungsi transfer grafik tersebut adalah $y=0,294 \ln (x)$ $+3,418$ dengan koefisien determinasi $R^{2}=0,966$. Nilai koefisien determinasi yang didapatkan mendekati 1 yang dapat disimpulkan bahwa sensor ini berfungsi dengan baik. Dari grafik tersebut didapatkan bahwa semakin jauh jarak sensor dari api maka tegangan yang dihasilkan semakin besar. Hal ini terjadi karena panas dari api yang diterima sensor semakin kecil, begitu juga sebaliknya.

\subsection{Pengujian Motor Servo SG-90}

Pengujian motor servo dilakukan bertujuan untuk mengetahui apakah sensor dapat bekerja dengan baik. Pengujian dilakukan pada 2 motor servo. Pengujian motor servo dilakukan terhadap variasi sudut yang diinput di dalam program Arduino IDE. Sudut yang diinputkan mulai dari sudut $0^{0}$ sampai $60^{\circ}$ ke kiri dan ke kanan dengan kenaikan sudut setiap $10^{\circ}$. Hasil pengujian menunjukkan bahwa motor servo dapat bekerja dengan baik sesuai dengan perintah yang diberikan.

Pengujian motor servo yang kedua dilakukan dengan variasi sudut yang berbeda dengan motor servo pertama. Motor servo ini digunakan untuk menggerakkan sensor ultrasonik agar 
lebih mudah mengukur jarak serong kiri dan serong kanan dari robot terhadap halangan yang ada . Sudut yang digunakan yaitu sudut $36^{\circ}$ untuk mengukur jarak robot dengan halangan di serong kiri, sudut $144^{0}$ untuk mengukur jarak robot dengan halangan di serong kanan, sudut $90^{\circ}$ adalah posisi awal dari sensor yaitu sensor mengahadap lurus kedepan. Dari hasil pengujian dapat dilihat bahwa sensor dapat bekerja dengan baik sesuai dengan program yang diberikan.

\subsection{Pengujian Gerak Roda Robot}

Pengujian gerak robot dilakukan bertujuan untuk melihat kemampuan motor DC sebagai penggerak roda robot apakah dapat bekerja dengan baik. Pengujian dilakukan pada 2 buah roda yang dilengkapi motor DC. Kedua motor DC tersebut dihubungkan ke modul L298N dan Arduino UNO R3. Pengujian gerak robot dilihat dari kesesuaian gerakan roda terhadap program yang diinputkan pada Arduino UNO R3 yaitu maju, mundur, kiri dan kanan. Pengujian dilakukan dengan penginputan manual dari pengguna sesuai dengan gerakan yang diinginkan.

Jika diketikkan angka "1" maka robot akan bergerak berhenti, jika diketikkan angka " 2 " maka robot akan bergerak maju, jika diketikkan angka" 3" maka robot akan bergerak ke muundur, jika diketikkan angka " 4 " maka robot kanan bergerak ke kanan, jika diketikkan angka "5" maka robot akan bergerak ke kiri. Dari hasil pengujian dapat dilihat bahwa semua perintah yang diberikan berhasil dilakukan oleh roda robot.

\subsection{Hasil Pengujian Kamera Wifi}

Pengujian kamera wifi dilakukan dengaan cara menghubungkan kamera dengan android melalui wifi. Setelah wifi dari android dan kamera tersambung, maka akan tampil gambar yang ditangkap kamera pada android. Kamera wifi ini diletakkan di bagian depan robot untuk melihat keadaan disekitar robot. Kamera ini bisa menangkap gambar sampai sudut $170^{\circ}$. Dari hasil pengujian dapat dilihat bahwa gambar yang dihasilkan sangat bersih dan perekaman video berjalan lancar yang dapat dilihat pada Gambar 9.

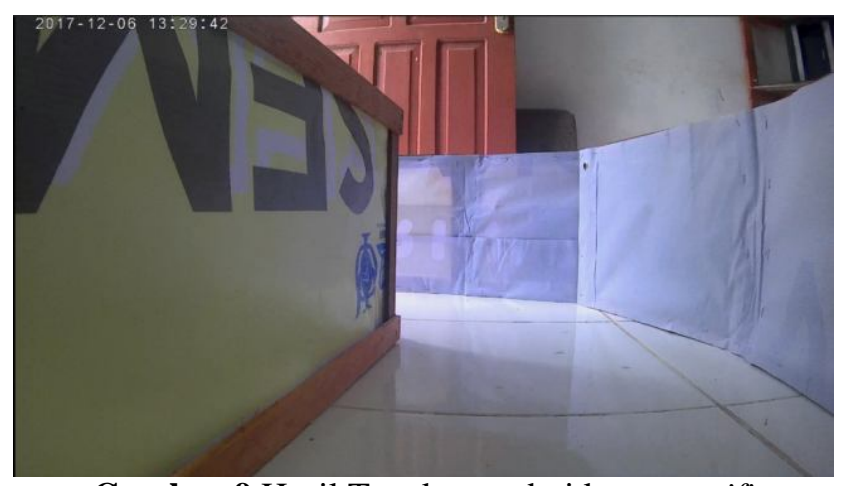

Gambar 9 Hasil Tangkapan dari kamera wifi

\subsection{Hasil Robot Secara Keseluruhan}

Pengujian robot secara keseluruhan dilakukan bertujuan untuk mengetahui keberhasilan robot dalam mendeteksi, menemukan dan memadamkan api pada sirkuit. Api yang digunakan dalam pengujian ini adalah api lilin.

Gambar 10 memperlihatkan bahwa robot bergerak dari ujung lorong dan terus bergerak menuyusuri setiap sudut sirkuit. Api lilin diletakkan di sudut ruangan.Untuk melakukan pengujian robot secara keseluruhan maka semua komponen robot sudah dirakit dan program keseluruhan robot diinputkan. Pada saat pengujian dilakukan di sirkuit dapat dilihat bahwa robot bisa menelusuri sirkuit, mendeteksi api dan memadamkannya. Sensor api bisa mendeteksi api dengan baik jika posisi api berada sejajar dengan sensor. Dari pengujian ini dapat dilihat bahwa robot berhasil mendeteksi api berdasarkan tegangan keluaran dari sensor api itu sendiri. Jika tegangan keluaran dari sensor api kecil 4,1 V maka pompa air langsung bisa otomatis aktif untuk memadamkan api. Namun sensor ini tidak bisa mendeteksi jarak jika posisi sensor ultrasonik terhadap dinding/objek dalam kondisi serong. Hal ini terjadi karena sudut pantul gelombang ultrasonik lebih besar dari $15^{0}$ sehingga receiver sensor tidak dapat menangkap 
gelombang yang dipantulkan objek dengan baik. Kondisi ini mengakibatkan pengukuran jarak menjadi error dan berpengaruh pada gerak robot.

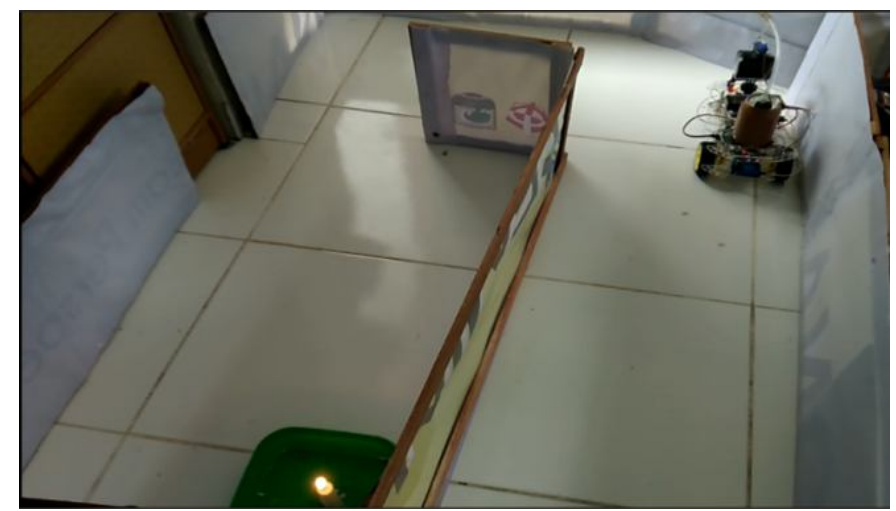

Gambar 10 Pengambilan data pada sirkuit robot

\section{KESIMPULAN}

Penelitian ini memperlihatkan bahwa robot cerdas pemadam api beroda dengan pemantauan berbasis wifi telah berhasil dikembangkan. Robot dapat menulusuri sirkuit, mememantau keadaan sekitar, mendeteksi api dan memadamkannya dengan baik. Robot berhasil mendeteksi api dan memadamkannya berdasarkan tegangan keluaran dari sensor api KY-026. Pada saat tegangan sensor berada dibawah 4,1 V maka sensor akan mengaktifkan pompa air dan motor servo untuk memadamkan api lilin. Namun sensor ultrasonik tidak bisa mendeteksi jarak jika posisi sensor terhadap dinding/objek dalam kondisi serong. Hal ini terjadi karena sudut pantul gelombang ultrasonik lebih besar dari $15^{0}$ sehingga receiver sensor tidak dapat menangkap gelombang yang dipantulkan objek dengan baik. Kondisi ini mengakibatkan pengukuran jarak menjadi error dan berpengaruh pada gerak robot.

\section{DAFTAR PUSTAKA}

Alfith, "Perancangan Robot Cerdas Pemadam Api dengan Sensor Thermal Array TPA 81 berbasis mikrokontroller ATMega 2560", Jurnal Teknik Elektro ITP, 2015, Vol.5 No.2 hal 95-102.

Jupii, K., dan Toar F. A. V., "Robot Cerdas Berkaki Pemadam Api", Jurnal Widya Teknik, Fakultas Teknik, Universitas Katolik Widya Mandala, 2008, Vol.7 No.2 hal 168-177.

Lubis, BH., Sekilas tentang Robot Beroda (Jurusan Pendidikan Fisika, Universitas Pendidikan Indonesia, Bandung, 2010).

Suryatini, F., Kustija, J., Haritman E., "Robot Cerdas Pemadam Api Menggunakan Ultrasonic Range Finder dan UVTron Flame Detector Berbasis Mikrokontroler Atmega 128", Jurnal Electrans, 2013, Vol.12 No.1 hal 29-38.

Ristekdikti, "Kontes Robot Pemadam Api Indonesia (KRPAI) 2017”, Direktorat Kemahasiswaan, Kementrian Riset Teknologi dan Pendidikan Tinggi, Indonesia, 2017 